\title{
Verification of Medium Range Weather Forecast Issued for Jammu Region to Generate Agromet Advisory
}

\author{
Veena Sharma $^{1 *}$ and Mahender Singh ${ }^{2}$ \\ ${ }^{1}$ Agromet Section, SKUAST-J, Chatha, Jammu-180009, J\&K, India \\ ${ }^{2}$ Agromet Section, SKUAST-Jammu, J\&K, India \\ *Corresponding author
}

\begin{tabular}{|l|}
\hline Key w o r d s \\
Weather forecast, \\
Meteorological, \\
Agromet advisory \\
\hline Article Info \\
\hline $\begin{array}{l}\text { Accepted: } \\
\text { 04 February } 2018 \\
\text { Available Online: } \\
\text { 10 March 2018 }\end{array}$ \\
\hline
\end{tabular}

A B S T R A C T
Weather forecast issued by India meteorological department and value added by Met Centre Srinagar was compared with actual weather data recorded at Agrometerological Observatory AMFU-Chatha to assess the validity and accuracy of weather forecast during 2016-17. Various test criteria were used to test the reliability and accuracy of the forecasted weather. The results indicated that correct forecast for rainfall was found to be maximum $(99.26 \%)$ in post monsoon season followed by winter season $(70.58 \%)$, pre monsoon season $(59.23 \%)$ and monsoon season $(40.22 \%)$. The correct maximum temperature values were found to be maximum in the post monsoon season $(55.50 \%)$ followed by monsoon season (34.45 \%), pre monsoon season (32.63\%) and winter season $(31.89 \%)$. The minimum temperature values were found to be least predicted. The maximum correct values of morning relative humidity (Max. RH) were found in the monsoon season $(57.08 \%)$ followed by post monsoon season $(41.65 \%)$. In the pre monsoon season and winter season the correct values were 34.39 and 14.76 per cent, respectively. The efficiency of forecast was good for day first, second, third and fourth and poor for fifth day. But fifth day (Saturday) in Tuesday advisory becomes second day in following Friday advisory similarly fifth day (Tuesday) in Friday advisory becomes first day in following Tuesday advisory so poor efficiency of forecast for fifth day does not affect overall efficiency of forecast. Correlation coefficients were derived between the forecasted and observed values during different seasons. RMSE calculated for all the five days during all the seasons indicates forecast value in agreement with observed value.

\section{Introduction}

The success or failure of agriculture crop production is mainly determined by the weather parameters of a given location. Weather manifests its influence on agricultural operations and farm production through its effects on soil and plant growth. Weather cannot be managed in favour of crop growth but its effects can be minimized by adjusting with the advanced knowledge of aberrant or unfavourable weather events such as drought, flood cold wave, and heat wave etc. agricultural operations can be delayed or advanced with the help of advanced information on weather from 3 to 10 days. There is enough scope to prevent losses due to unfavorable weather conditions by taking 
precautionary measures in time based on weather information. It is now very much clear that for deriving the maximum yield for agriculture, one must have a proper knowledge of the weather forecast in real time basis. Weather forecast helps to increase agriculture production, reduce losses, risks, reduce costs of inputs, improve quality of yield, increase efficiency in the use of water, labor and energy and reduce pollution with judicious use of agricultural chemicals. Rathore et al., (2001) discussed the weather forecasting scheme operational at NCMRWF for issuing location specific weather forecast three days in advance to the Agromet Advisory Services units located at different parts of India. Agro-meteorological service rendered by IMD, Ministry of Earth Sciences is an innovative step to contribute to weather information based crop/livestock management strategies and operations dedicated to enhancing crop production by providing real time crop and location specific agromet services with outreach to village level. This indeed has a potential to change the face of India in terms of food security and poverty alleviation (Palkhiwala, 2012).

\section{Materials and Methods}

Medium range forecast is issued by India Meteorological Department, New Delhi issued and value added by Meteorological Centre, Srinagar on various weather parameters viz., amount of rainfall, cloud cover, maximum and minimum temperature, wind speed and direction for Jammu district. The observed meteorological data at the Agro meteorological observatory, SKUAST-J, Chatha was compared to value added forecast to assess the validity of weather forecasts for the months of March 2016 to February, 2017. For the analysis of the verification of the forecast data, the year was divided into four groups on seasonal basis viz., pre, (MarchMay), monsoon (June-September), Post monsoon (October- December), winter (January-February). Different verification methods were used to assess the reliability of forecast values of weather parameters. The forecast of rainfall, cloud cover, temperature, wind speed and direction have been verified by calculating the error structure. Different scores such as threat score, H.S. score, true skill score and ratio score were calculated to test the weather forecast for rainfall during 2016-17.

During 2016-17, based on forecasts of 365 days, crop weather bulletins were prepared and issued on each Tuesday (53) and Friday (52) for the benefit of farmers of Jammu district. Total of 105 bulletins were prepared. Verification with observed and forecast value of Jammu district was analyzed. Verification of forecast was done day basis i.e., first day, second day, third day, fourth day and Fifth day.

The validation methods as suggested by Singh et al., (1999) were used.

\section{Error structure}

Rainfall: Correct $\pm 10 \%$, Usable $\pm 20 \%$,

Temperature: Correct $\pm 1^{\circ} \mathrm{C}$, Usable $\pm 2^{\circ} \mathrm{C}$

Relative humidity Correct $\pm 10 \%$, Usable $\pm 20 \%$

Cloud cover: Correct \pm 1 Okta, Usable \pm 2 Okta

Wind speed: Correct $\pm 3 \mathrm{kmph}$, Usable \pm 6 kmph

Wind direction: Correct $\pm 10^{\circ}$, Usable $\pm 30^{\circ}$

\section{Discrete variable}

The rainfall is a categorical or discrete variable, verified by using the contingency 
table approach (Murphy and Winkler, 1987; Murphy et al., 1989 and Schafer 1990). It gives information about the skill of forecast as well as types of errors that occurs in the forecast. The ratio score (Y/N basis), Critical Success Index (CSI), Heidke Skill Score (HSS) and Hansen and Kuipers Score (HKS) are adopted for verification of predicted rainfall.

$\mathrm{Y}=\mathrm{Yes}$ and $\mathrm{N}=\mathrm{No}$

First letter in the pair is observed rainfall while the second depicts the predicted rainfall.

YY $(\mathrm{H})=$ No. of hits (Rainfall has been observed as well as forecasted)

NY $(F)=$ No. of false alarms (Rainfall has been predicted but not observed)

YN $(\mathrm{M})=$ No. of misses (Rainfall has been observed but not predicted)

$\mathrm{NN}(Z)=$ No. of correct predictions of no rain (neither predicted nor observed)

Total no. of cases is given by $\mathrm{N}$ and this also represents the number of days for which the forecast is given.

\section{Threat Score}

Threat score (TS) measured the fraction of observed and / or forecast events that were correctly predicted. Threat score was calculated using the following formula:

$\mathrm{TS}=$ hits $/$ (hits + misses + false alarms)

Where Hits means forecast for rainfall was yes and it was observed, miss means no forecast for rainfall but it was observed, false alarm means forecast for rainfall was yes but it was not observed and correct negative means no forecast for rainfall and it was not observed.
The value of threat score ranges between 0 to 1,0 indicates least accuracy of forecast, and lindicate perfect forecast. It explains about how well did the forecast yes event correspond to observed yes events.

\section{Heidke Skill Score (H.S. Score)}

Heidke skill score (H.S. Score) measured the fraction of correct forecasts after eliminating those forecasts which would be correct due purely to random chance. Its value ranges between minus infinity to 1,0 indicates no skill and 1 indicates perfect score. The H.S. score was calculated as follows:

H.S. Score $=\{($ hits + correct negative $)-$ (expected correct) random $\} /\{\mathrm{N}$-(expected correct)random \}

(Expected correct $)$ random $=\{$ (hits+ misses $)$ (hits+false alarms) + (correct negative + misses) (correct negative + false alarms) $\} / \mathrm{N}$

H. S. score explain the accuracy of the forecast relative to that of random chance.

\section{Hanssen and Kuipers (HKS) (True skill score)}

Hanssen and Kuipers (True skill score) was calculated as follows:

HK score $=\{$ hits $/($ hits + misses $)\}-\{$ false alarms / (false alarms + correct negatives) $\}$

The value of HK score ranges between -1 to 1 , 0 indicates no skill and 1 indicate perfect score.

It explain how well did the forecast separate the yes event from the no event.

\section{Forecast accuracy (ACC) or Ratio Score}

Ratio score was calculated as follows:

Ratio score $=($ hits + correct negative $) / \mathrm{N}$ 
Where $\mathrm{N}$ is total number of forecast

It range between 0 to 1,0 indicates no skill and lindicate perfect score. Sometimes, this score is multiplied by $100 \%$ and it is referred to as the percent correct, or the percentage of forecast correct (PFC).

It explains fraction of the total forecast events when the categorical forecast correctly predicted event and non-event.

\section{The root mean square error (RMSE)}

The root mean square error (RMSE) was calculated using the following formula:

$\mathrm{RMSE}=\mathrm{SQRT}\left(1 / \mathrm{N} \sum(\mathrm{Fi}-\mathrm{Oi})^{2}\right.$

Where,

$\mathrm{N}=$ Sample size/ no. of observations

$\mathrm{Fi}=$ Forecasted value

$\mathrm{Oi}=$ Observed value

The RMSE values indicate the degree of error in the forecast. The lower values of RMSE indicate less difference between observed and forecasted value.

\section{Results and Discussion}

The verification is qualitative or quantitative so as to bring out the nature of the forecast errors. Forecast verification serves the role of identifying the accuracy of forecasts, with the goal of improving future predictions and also emphasizes accuracy and skill of prediction.

Verification with observed and quantitative forecast for 4 weather parameters viz., rainfall, maximum and minimum temperatures, and relative humidity for Jammu District was analyzed. Following results were obtained Correct values for rainfall in Table 3 expresses accuracy ranged from 48.57-100 percent, 38.24-96.3 percent, 40-100 percent, 27.27-100 percent and 47.06-100 percent for first, second, third, fourth and fifth day respectively for four seasons viz. monsoon, post monsoon, pre monsoon and winter. The correct forecast for rainfall was found to be maximum (99.26 $\%$ ) in post monsoon season followed by winter season $(70.58 \%)$, pre monsoon season $(59.23 \%)$ and monsoon season $(40.22 \%)$.

Correct values for maximum temperature in Table 4 expresses accuracy ranged from 39.99-76.92 percent, 24-48.15 percent, 1653.85 percent, 27.78-61.54 percent and 27.7837.04 percent for first, second, third, fourth and fifth day respectively for four seasons viz. monsoon, post monsoon, pre monsoon and winter. The correct maximum temperature values were found to be maximum in the post monsoon season $(55.50 \%)$ followed by monsoon season (34.45\%), pre monsoon season $(32.63 \%)$ and winter season (31.89 $\%)$.

Error structure (correct) for minimum temperature in Table 5 expresses accuracy ranged from 7.69-51.52 percent, 18.52-28.13 percent, 11.11-30.77 percent, 8.33-30.77 percent and 12-26.47percent for first, second, third, fourth and fifth day respectively for four seasons viz. monsoon, post monsoon, pre monsoon and winter.

The minimum temperature values were found to be least predicted.

Error structure (correct) for Minimum Relative Humidity expresses accuracy ranged from 26.92-82.35 percent, 33.33-75 percent, 26.92-76 percent, 42.31-66.67 percent and 40.74-70.59 percent for first, second, third, fourth and fifth day respectively for four seasons viz. monsoon, post monsoon, pre monsoon and winter. 
Table.1 Day of issue of forecast/agroadvisory

\begin{tabular}{|c|c|c|c|c|c|}
\hline $\begin{array}{c}\text { Day of Issue of } \\
\text { Forecast/agroadvisory }\end{array}$ & $\mathrm{I}^{\text {st }}$ Day & $2^{\text {nd }}$ Day & $3^{\text {rd }}$ Day & $4^{\text {th }}$ Day & $5^{\text {th }}$ Day \\
\hline Tuesday & Tuesday & Wednesday & Thursday & Friday & Saturday \\
\hline Friday & Friday & Saturday & Sunday & Monday & Tuesday \\
\hline
\end{tabular}

Table. 2 The following $2 * 2$ contingency table is used for calculation of the various skill scores and verification of the rainfall forecast

\begin{tabular}{l|l|l|l|}
\hline \multirow{2}{*}{$\begin{array}{l}\text { Event } \\
\text { forecasted }\end{array}$} & Yes & No & Marginal total \\
\hline Yes & H(YY) & F(NY) & YY+NY $(\mathrm{H}+\mathrm{F})$ \\
\hline No & M(YN) & Z(NN) & YN+NN (M+Z) \\
\hline Marginal total & YY+YN $(\mathrm{H}+\mathrm{M})$ & $\mathrm{NY}+\mathrm{NN}(\mathrm{F}+\mathrm{Z})$ & $\begin{array}{l}\mathrm{N}(\mathrm{YY}+\mathrm{NY}+\mathrm{YN}+\mathrm{NN}) \\
\mathrm{N}(\mathrm{H}+\mathrm{F}+\mathrm{M}+\mathrm{Z})\end{array}$ \\
\cline { 3 - 4 } & & &
\end{tabular}

Table.3 Verification of rainfall forecast during 2016-17

\begin{tabular}{|c|c|c|c|c|} 
Season & Monsoon & $\begin{array}{c}\text { Post } \\
\text { monsoon }\end{array}$ & $\begin{array}{c}\text { Pre } \\
\text { monsoon }\end{array}$ & winter \\
\hline Day 1 & 48.57 & 100 & 57.69 & 76.47 \\
\hline Day 2 & 38.24 & 96.3 & 62.96 & 76.47 \\
\hline Day 3 & 40 & 100 & 64 & 61.11 \\
\hline Day 4 & 27.27 & 100 & 46.15 & 66.67 \\
\hline Day 5 & 47.06 & 100 & 65.38 & 72.22 \\
\hline Mean & 40.228 & 99.26 & 59.236 & 70.588 \\
\hline
\end{tabular}

Table.4 Verification of Maximum Temperature forecast during 2016-17

\begin{tabular}{|c|c|c|c|c|}
\hline Season & Monsoon & $\begin{array}{c}\text { Post } \\
\text { Mon. }\end{array}$ & $\begin{array}{c}\text { Pre- } \\
\text { Mon. }\end{array}$ & winter \\
\hline Day 1 & 39.39 & 76.92 & 57.69 & 41.18 \\
\hline Day 2 & 37.5 & 48.15 & 24 & 29.41 \\
\hline Day 3 & 37.5 & 53.85 & 16 & 33.33 \\
\hline Day 4 & 31.43 & 61.54 & 37.5 & 27.78 \\
\hline Day 5 & 26.47 & 37.04 & 28 & 27.78 \\
\hline Mean & 34.458 & 55.5 & 32.63 & 31.896 \\
\hline
\end{tabular}


Table.5 Verification of minimum temperature forecast during 2016-17

\begin{tabular}{|c|c|c|c|c|}
\hline $\begin{array}{c}\text { Season } \\
\text { Day }\end{array}$ & Monsoon & $\begin{array}{c}\text { Post } \\
\text { Mon. }\end{array}$ & $\begin{array}{c}\text { Pre- } \\
\text { Mon. }\end{array}$ & Winter \\
\hline Day 1 & 51.52 & 15.38 & 7.69 & 29.41 \\
\hline Day 2 & 28.13 & 18.52 & 20 & 23.53 \\
\hline Day 3 & 20 & 30.77 & 12 & 11.11 \\
\hline Day 4 & 20 & 30.77 & 8.33 & 11.11 \\
\hline Day 5 & 26.47 & 26.09 & 12 & 16.67 \\
\hline Mean & 29.224 & 24.306 & 12.004 & 18.366 \\
\hline
\end{tabular}

Table.6 Verification of minimum relative humidity forecast during 2016-17

\begin{tabular}{|c|c|c|c|c|}
\hline $\begin{array}{c}\text { Season } \\
\text { Day }\end{array}$ & Monsoon & $\begin{array}{c}\text { Post } \\
\text { Mon. }\end{array}$ & $\begin{array}{c}\text { Pre- } \\
\text { Mon. }\end{array}$ & Winter \\
\hline Day 1 & 60.61 & 26.92 & 65.38 & 82.35 \\
\hline Day 2 & 75 & 33.33 & 52 & 58.82 \\
\hline Day 3 & 59.38 & 26.92 & 76 & 50 \\
\hline Day 4 & 48.57 & 42.31 & 58.33 & 66.67 \\
\hline Day 5 & 70.59 & 40.74 & 48 & 50 \\
\hline Mean & 62.83 & 34.044 & 59.942 & 61.568 \\
\hline
\end{tabular}

Table.7 Verification of maximum relative humidity forecast during 2016-17

\begin{tabular}{|c|c|c|c|c|}
\hline $\begin{array}{c}\text { Season } \\
\text { Day }\end{array}$ & Monsoon & $\begin{array}{l}\text { Post- } \\
\text { Mon }\end{array}$ & $\begin{array}{l}\text { Pre- } \\
\text { Mon }\end{array}$ & Winter \\
\hline Day 1 & 72.73 & 46.15 & 38.46 & 17.64 \\
\hline Day 2 & 53.13 & 40.74 & 24 & 11.76 \\
\hline Day 3 & 43.75 & 42.31 & 36 & 16.66 \\
\hline Day 4 & 62.86 & 34.62 & 37.5 & 5.55 \\
\hline Day 5 & 52.94 & 44.44 & 36 & 22.22 \\
\hline Mean & 57.082 & 41.652 & 34.392 & 14.766 \\
\hline
\end{tabular}

Table.8 Verification of wind speed forecast during 2016-17

\begin{tabular}{|c|c|c|c|c|}
\hline $\begin{array}{c}\text { Season } \\
\text { Day }\end{array}$ & Monsoon & $\begin{array}{c}\text { Post- } \\
\text { Mon }\end{array}$ & $\begin{array}{c}\text { Pre- } \\
\text { Mon }\end{array}$ & Winter \\
\hline Day 1 & 100 & 100 & 100 & 100 \\
\hline Day 2 & 100 & 100 & 100 & 100 \\
\hline Day 3 & 100 & 100 & 100 & 100 \\
\hline Day 4 & 100 & 100 & 100 & 100 \\
\hline Day 5 & 100 & 100 & 100 & 100 \\
\hline Mean & 100 & 100 & 100 & 100 \\
\hline
\end{tabular}


Table.9 Verification of cloud cover forecast during 2016-17

\begin{tabular}{|c|c|c|c|c|}
\hline $\begin{array}{c}\text { Season } \\
\text { Day }\end{array}$ & Monsoon & $\begin{array}{l}\text { Post- } \\
\text { Mon }\end{array}$ & $\begin{array}{l}\text { Pre- } \\
\text { Mon }\end{array}$ & Winter \\
\hline Day 1 & 39.39 & 80.77 & 53.85 & 47.06 \\
\hline Day 2 & 43.75 & 81.48 & 64 & 70.59 \\
\hline Day 3 & 46.88 & 65.38 & 68 & 72.22 \\
\hline Day 4 & 51.43 & 69.23 & 58.33 & 55.56 \\
\hline Day 5 & 43.75 & 85.19 & 68 & 66.67 \\
\hline Mean & 45.04 & 76.41 & 62.43 & 62.42 \\
\hline
\end{tabular}

Table.10 Verification of wind direction forecast during 2016-17

\begin{tabular}{|c|c|c|c|c|}
\hline $\begin{array}{c}\text { Season } \\
\text { Day }\end{array}$ & Monsoon & $\begin{array}{l}\text { Post- } \\
\text { Mon }\end{array}$ & $\begin{array}{l}\text { Pre- } \\
\text { Mon }\end{array}$ & Winter \\
\hline Day 1 & 15.15 & 15.38 & 7.69 & 17.64 \\
\hline Day 2 & 31.25 & 7.4 & 4 & 11.76 \\
\hline Day 3 & 21.87 & 15.38 & 8 & 16.66 \\
\hline Day 4 & 21.21 & 11.53 & 8.33 & 5.55 \\
\hline Day 5 & 25 & 3.7 & 12 & 22.22 \\
\hline Mean & 22.896 & 10.678 & 8.004 & 14.766 \\
\hline
\end{tabular}

Table.11 Threat Score/CSI for 2016-17

\begin{tabular}{|c|c|c|c|c|}
\hline $\begin{array}{c}\text { Season } \\
\text { Day }\end{array}$ & Monsoon & $\begin{array}{c}\text { Post- } \\
\text { Mon }\end{array}$ & $\begin{array}{l}\text { Pre- } \\
\text { Mon }\end{array}$ & Winter \\
\hline Day 1 & 0.52 & - & 0.36 & 0.5 \\
\hline Day 2 & 0.45 & - & 0.33 & 0.67 \\
\hline Day 3 & 0.18 & - & 0.3 & 0.43 \\
\hline Day 4 & 0.33 & - & 0.31 & 0.5 \\
\hline Day 5 & 0.5 & - & 0.33 & 0.57 \\
\hline Mean & 0.44 & - & 0.44 & 0.64 \\
\hline
\end{tabular}

Table.12 Ratio Score during 2016-17

\begin{tabular}{|c|c|c|c|c|}
\hline $\begin{array}{c}\text { Season } \\
\text { Day }\end{array}$ & Monsoon & $\begin{array}{c}\text { Post- } \\
\text { Mon }\end{array}$ & $\begin{array}{l}\text { Pre- } \\
\text { Mon }\end{array}$ & Winter \\
\hline Day 1 & 71.43 & 100 & 73.08 & 88.24 \\
\hline Day 2 & 64.71 & 100 & 76 & 88.24 \\
\hline Day 3 & 48.57 & 100 & 72 & 77.78 \\
\hline Day 4 & 51.52 & 100 & 62.5 & 83.33 \\
\hline Day 5 & 73.53 & 100 & 76 & 83.33 \\
\hline Mean & 61.952 & 100 & 71.916 & 84.184 \\
\hline
\end{tabular}


Table.13 RMSE during 2016-17

\begin{tabular}{|c|c|c|c|c|}
$\begin{array}{c}\text { Season } \\
\text { Day }\end{array}$ & Monsoon & $\begin{array}{c}\text { Post- } \\
\text { Mon }\end{array}$ & $\begin{array}{l}\text { Pre- } \\
\text { Mon }\end{array}$ & Winter \\
\hline Day 1 & 22.8 & 0 & 3.32 & 5.53 \\
\hline Day 2 & 21.35 & 0 & 2.25 & 4.67 \\
\hline Day 3 & 10.59 & 0 & 3.37 & 4.66 \\
\hline Day 4 & 22.03 & 0 & 4.76 & 5.56 \\
\hline Day 5 & 27.7 & 0 & 3.26 & 3.77 \\
\hline Mean & 20.894 & 0 & 3.392 & 4.838 \\
\hline
\end{tabular}

Table.14 Hanssen and Kuipers (True skill score) during 2016-17

\begin{tabular}{|c|c|c|c|c|}
\hline $\begin{array}{c}\text { Season } \\
\text { Day }\end{array}$ & Monsoon & $\begin{array}{l}\text { Post- } \\
\text { Mon }\end{array}$ & $\begin{array}{l}\text { Pre- } \\
\text { Mon }\end{array}$ & Winter \\
\hline Day 1 & 0.54 & - & 0.42 & 0.87 \\
\hline Day 2 & 0.34 & - & 0.51 & 0.85 \\
\hline Day 3 & -0.06 & - & 0.35 & 0.54 \\
\hline Day 4 & 0.1 & - & 0.22 & 0.61 \\
\hline Day 5 & 0.51 & - & 0.51 & 0.79 \\
\hline Mean & 0.286 & - & 0.402 & 0.732 \\
\hline
\end{tabular}

Table.15 Heidke Skill Score (H.S. Score) during 2016-17

\begin{tabular}{|c|c|c|c|c|}
\hline $\begin{array}{c}\text { Season } \\
\text { Day }\end{array}$ & Monsoon & $\begin{array}{c}\text { Post- } \\
\text { Mon }\end{array}$ & $\begin{array}{l}\text { Pre- } \\
\text { Mon }\end{array}$ & Winter \\
\hline Day 1 & 0.45 & - & 0.35 & 0.6 \\
\hline Day 2 & 0.31 & - & 0.36 & 0.72 \\
\hline Day 3 & -0.04 & - & 0.29 & 0.45 \\
\hline Day 4 & 0.08 & - & 0.19 & 0.56 \\
\hline Day 5 & 0.46 & - & 0.36 & 0.62 \\
\hline Mean & 0.252 & - & 0.31 & 0.59 \\
\hline
\end{tabular}

Table.16 Correlation Coefficients between observed and forecasted values for rainfall during different seasons during 2016-17

\begin{tabular}{|c|c|c|c|c|}
$\begin{array}{c}\text { Season } \\
\text { Day }\end{array}$ & Monsoon & $\begin{array}{c}\text { Post- } \\
\text { Mon }\end{array}$ & $\begin{array}{c}\text { Pre- } \\
\text { Mon }\end{array}$ & Winter \\
\hline Day 1 & 0.1 & - & 0.76 & 0.7 \\
\hline Day 2 & 0.51 & - & 0.9 & 0.96 \\
\hline Day 3 & 0.16 & - & 0.68 & 0.77 \\
\hline Day 4 & 0.06 & - & 0.48 & 0.59 \\
\hline Day 5 & 0.23 & - & 0.92 & 0.87 \\
\hline Mean & 0.21 & - & 0.75 & 0.78 \\
\hline
\end{tabular}


The maximum correct value of evening relative humidity (Min. $\mathrm{RH}$ ) was found in the monsoon season $(62.83 \%)$ followed by winter season $(61.56 \%)$, pre monsoon $(59.94 \%)$ and post season (34.04\%) (Table 6).

Error structure (correct) for Maximum Relative Humidity expresses accuracy ranged from 38.46-72.73 percent, 24-53.13 percent, 16.66-43.75 percent, 5.55-62.86 percent and 22.22-52.94 percent for first, second, third, fourth and fifth day respectively for four seasons viz. monsoon, post monsoon, pre monsoon and winter. The maximum correct values of morning relative humidity (Max. $\mathrm{RH})$ were found in the monsoon season $(57.08 \%)$ followed by post monsoon season $(41.65 \%)$. In the pre monsoon season and winter season the correct values were 34.39 and 14.76 per cent, respectively (Table 7).

Correct values for wind speed expresses accuracy was 100 percent for all five days during all the four seasons (Table 8). Correct cloud cover values expresses accuracy ranged from 39.39-80.77 percent, 43.75-81.48 percent, 46.88-72.22 percent, 51.43-69.23 percent and 43.75-85.19 percent for first, second, third, fourth and fifth day respectively for four seasons viz. monsoon, post monsoon, pre monsoon and winter. The maximum correct values of cloud cover were found in the post monsoon season $(76.41 \%)$. In pre monsoon season and winter season the correct value was 62.4 followed by monsoon season (45.04\%) (Table 9).

The correct wind direction values were found to be least predicted. The prediction accuracy was less than 50\%.The results highlight the need for improvement or extra care in making predication of wind direction (Table 10). Similar results showing low accuracy in wind direction prediction were also reported for Dharwad district of Karnataka by Mummigatti et al., (2013).
To verify the forecast, 2 X 2 contingency table (Table 2) between forecasted daily and observed rainfall events was made and based upon this table, different scores for evaluating the skill rainfall forecast were worked out.

Validation of rainfall forecast over different seasons revealed following facts:

Table 11 depicts the threat score value was higher during winter season followed equally by monsoon and pre monsoon season indicating that observed rainfall during winter was nearer to the predicted compared to monsoon and pre monsoon season. No threat score values were obtained during post monsoon season, as neither rainfall was observed nor was the forecast made during the said season. Similar observations were also reported by Vashisth et al., (2008).

Table 12 shows the efficiency of rainfall forecast as measured by ratio score ranged from 71.43 percent to 100 percent for first day, 64.71 to 100 per cent for second day, 48.57 to 100 per cent for third day, 51.52 to 100 per cent for fourth day and 73.53 to 100 per cent for fifth day. The efficiency of rainfall was good for day first, second, third day \& also for fourth and fifth day. But fourth and fifth day (Saturday) in Tuesday forecast becomes second day in following Friday forecast similarly fifth day (Tuesday) in Friday forecast becomes first day in following Tuesday forecast so forecast for fifth day does not affect overall efficiency of rainfall forecast. Results indicate that the performance of ensemble multi model under Jammu region to be better in all the seasons. Similar observations were also reported by Manjappa and Yeledalli (2013).

RMSE calculated for all the five days during pre-monsoon, post monsoon and winters seasons was less than 5 indicating forecast value in agreement with observed value. 
RMSE ranged from 0 to $22.8,0$ to $21.35,0$ to 10.59 for I, II and III day respectively (Table 13). Rainfall forecast performance was very good with low RMSE during all the 3 days in all the seasons except monsoon (Table 13). Similar results were obtained by Sarmah et al., 2015.

The value of $\mathrm{HK}$ skill score ranged from 0.42 to $0.87,0.34$ to $0.85,-0.06$ to 0.54 for I, II and III day respectively (Table 14) indicating forecast for rainfall was almost perfect during 2016-17.

There were no values for post monsoon season because rainfall did not occur in this season and no rainfall forecast became 100 percent correct. The positive HK scores indicated the reliability of forecast to be satisfactory in all the seasons (Table 14). Similar observations were also reported by Sarmah et al., 2015; Rana et al., (2013). The average HSS score value represented to the trend of HK score. The value of HS skill score ranged from 0.35 to $0.6,0.31$ to 0.72 , $0.04,0$ to 0.45 for I, II and III day respectively (Table 15) indicating correctness of forecast. There were no values for post monsoon season as neither rainfall was observed nor was the forecast made for the said season (Table 15). Similar observations were reported by Joseph et al., (2017).

Correlation coefficients were derived between the forecasted and observed values during 2016-17 for different seasons (Table 16). It was observed that the forecast and observed values were better for I, II and III day. IV and $\mathrm{V}$ day forecast was not considered as every 5 days forecast covers IV and V day of earlier forecast as I and II day. Rainfall was highly correlated during winter and pre monsoon followed by monsoon season. There were no values for post monsoon season as neither rainfall was observed nor was the forecast made for the said season.
In Conclusion the performance of multi model (ENSEMBLE) for Jammu region was very good in all the seasons. The higher accuracy of rainfall prediction was noticed for day 1 to day 3. Fourth and fifth day (Saturday) in Tuesday forecast becomes second day in following Friday forecast similarly fifth day (Tuesday) in Friday forecast becomes first day in following Tuesday forecast so forecast for fifth day does not affect overall efficiency of rainfall forecast. The medium range weather forecasts with rainfall as one of the most important parameters were used for preparing agromet advisory bulletins for the farmers of study area which were very useful for scheduling of sowing, irrigation, agricultural operations and management of pest and diseases of field crops. As weather forecast is in agreement with observed weather, user community based on these forecast and its use in agromet advisory services could save losses / damages of the crops. The farmers feel it to be useful since they receive weather based advices on appropriate field operations and management.

\section{References}

Joseph, M., Murugan, E. and Hemalatha, M. 2017. Forecast Verification Analysis of Rainfall for Southern Districts of Tamil Nadu, India. Int. J. Curr. Microbiol.App.Sci (2017) 6(5): 299-306

Manjappa, K. and Yeledalli, S.B. 2013. Validation and assessment of economic impact of agro advisories issued based on medium range weather forecast for Uttara Kannada district of Karnataka. J. Agric. Sci. 26 (1): 36-39.

Mummigatti, U.V., Naveen, N.E., Thimme Gowda, P. and Hulihalli, U.K. (2013). Validation and assessment of economic impact of agro advisories issues based on medium range weather forecast for Dharwad district of Karnataka. Agric. Update. 8(1\&2): 260-264. 
Murphy, A. H., Brown, B. G. and Chen, Y. S. 1989. Diagnostic verification of temperature forecasts. American Meteorological Society. 4: 485-501.

Murphy, A.H. and Winkler, R.L. 1987. A General Framework for Forecast Verification. Monthly Weather Review.115: 1330-1338.

Palkhiwala, Kalpana. 2012. Agromet Advisory Services - Farmers Empowerment. Press information bureau, Government of India, special service and features, 15-May, 2012.

Rana, R.S., Sood, R., Aditya and Shekhar J. 2013. Validation of medium range weather forecasts in sub-temperate and sub-humid climate of western Himalayas. Indian Journal of Agricultural Sciences 83 (12): 1357-63.

Rathore, L.S., Gupta, Akhilesh and Singh, K.K. 2001. Medium range weather forecasting and agricultural production. Journal of Agric. Physics. 1(1): 43-47.
Sarmah, K., Neog, P., Rajbongshi, R. and Sarma, A. 2015. Verification and usability of medium ranged forecast for north bank plain zone of Assam, India. 2013. Mausam. 66(3), 585-594

Schafer, J.T. 1990. The critical success index as an indicator of warning skill. Wea. and Forecasting. 5: 570-575.

Singh, S.V., Rathore, L.S. and Trivedi, H.K.N. 1999. Verification of medium range weather forecasts. Guide for Agro-meteorological advisory services. National Centre for Medium Range Weather Forecasting. Department of Science and Technology, Government of India Publication, India, Pp 73-81.

Vashisth, A., Das, D.K., Bhagawati, G. and Sharma, P.K. 2008. Accuracy of Weather Forecast for Semi-arid Climate of Delhi for Agricultural Management Practices. Agric. Physics. 8: 51-58.

\section{How to cite this article:}

Veena Sharma and Mahender Singh. 2018. Verification of Medium Range Weather Forecast Issued for Jammu Region to Generate Agromet Advisory. Int.J.Curr.Microbiol.App.Sci. 7(03): 176-186. doi: https://doi.org/10.20546/ijcmas.2018.703.021 